\title{
PHYSICAL CONDITION COMPARISON BETWEEN FEMALE ATHLETE INDOOR HOCKEY OF EAST JAVA TEAM AND NATIONAL TEAM
}

Fitry Nachamory Oemar ${ }^{1}$, Irmantara Subagio ${ }^{2}$, Hayuris Kinandita ${ }^{3}$, Purwo Sri Rejeki ${ }^{1,3^{*}}$

${ }^{1}$ Sport Health Science Master Program, Faculty of Medicine, Universitas Airlangga, Surabaya, Indonesia, ${ }^{2}$ Sport Training Program, Faculty of Sport Sciences, Universitas Negeri Surabaya, Surabaya, Indonesia, ${ }^{3}$ Department of Physiology, Faculty of Medicine, Universitas Airlangga, Surabaya, Indonesia

\section{ABSTRACT}

This study purposed to describe physical condition differences between indoor hockey female athletes of East Java Team and National Team. Data sampling were taken from 12 indoor hockey female athletes of PON 2016 with age range 17-28 years old and 12 athletes of indoor hockey of Indonesia's National Team at SEA Games 2017 with age range 19-28 years old for comparison. Physical conditions measured were VO2max to represent endurance, abdominal muscle strength, speed and flexibility. Obtained data were then analyzed using SPSS. VO2max of East Java Team was $39.54 \pm 4.18 \mathrm{ml} / \mathrm{kg} / \mathrm{minute}$ and for National Team was $43.43 \pm 7.59 \mathrm{ml} / \mathrm{kg} /$ minute (?=0.14). For abdominal muscle strength, East Java Team had $41.50 \pm 7.01 \mathrm{~kg}$ and National Team had $51.83 \pm 3.32 \mathrm{~kg}(?=0.00)$. For speed, East Java Team had $3.59 \pm 0.30$ second and National Team had $3.94 \pm 0.38$ second $(?=0.51)$. For flexibility, East Java Team had $23.75 \pm 5.10 \mathrm{~cm}$ and National Team had $29.50 \pm 4.91 \mathrm{~cm}$ $(?=0.01)$. This study concluded that East Java Team physical condition was under National Team and it had significant differences at flexibility and abdominal muscle strength. Furthermore, optimal interventions were needed to improve both of those physical conditions.

Keywords: hockey; endurance; flexibility; strength; speed

\section{ABSTRAK}

Tujuan dari penelitian ini adalah untuk mendeskripsikan perbedaan kondisi fisik pada hoki indoor putri atlet Tim Jatim dan Timnas. Pengambilan sampel data diambil dari 12 atlet hoki indoor putri PON 2016 dengan rentang usia 17-28 tahun dan 12 atlet hoki indoor Timnas Indonesia SEA Games 2017 dengan rentang usia 19-28 tahun sebagai pembanding. Kondisi fisik yang diukur adalah VO2max yang mewakili daya tahan, kekuatan otot perut, kecepatan dan kelenturan. Data yang diperoleh

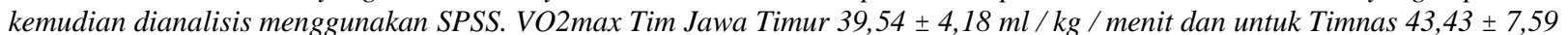
$\mathrm{ml} / \mathrm{kg} /$ menit $(?=0,14)$. Untuk kekuatan otot perut, Tim Jawa Timur 41,50 \pm 7,01 kg dan Timnas 51,83 $\pm 3,32 \mathrm{~kg}(?=0,00)$. Untuk kecepatan, Tim Jatim punya waktu 3,59 \pm 0,30 detik dan Timnas 3,94 \pm 0,38 detik $(?=0,51)$. Untuk fleksibilitas, Tim Jawa Timur memiliki 23,75 \pm 5,10 cm dan Tim Nasional 29,50 \pm 4,91 cm (? = 0,01). Dari data tersebut dapat disimpulkan bahwa kondisi fisik Tim Jawa Timur berada di bawah Timnas dan terdapat perbedaan yang signifikan pada kelenturan dan kekuatan otot perut. Selain itu, diperlukan intervensi yang optimal untuk memperbaiki kedua kondisi fisik tersebut.

Kata kunci: hoki; ketahanan; fleksibilitas; kekuatan; kecepatan

Correspondence: Purwo Sri Rejeki, Sport Health Science Master Program, Faculty of Medicine, Universitas Airlangga, Surabaya, Indonesia. E-mail: purwo_faal@yahoo.com

pISSN:2355-8393 • eISSN: 2599-056x • doi: 10.20473/fmi.v57i1.16209

- Fol Med Indones. 2020;57:58-62 • Received 28 Nov 2019 • Accepted 21 May 2020

- Open access under CC-BY-NC-SA license • Available at https://e-journal.unair.ac.id/FMI/

\section{INTRODUCTION}

Hockey is a sport with achievement that categorized as a sport game. In the hockey game, there are two teams that play against each other to score as much as possible. There are two kinds of hockey games that played up to the world championship which is field hockey, indoor hockey, dan ice hockey (FIH.com). The types of hockey that grow rapidly in Indonesia are field and indoor hockey. Indonesia's participation in international championship at indoor hockey in SEA 
Games 2017 has achieve silver medals and this potential is available for further development.

Every sports has its own characteristic that become identity and used as milestone to arrange training program (Mansur 2011). Indoor hockey has similar characteristic with futsal or basketball which, there is no limitation to exchange player and it also grouped as intermitten sport. Intermitten sport is a sport that need ability to suddenly changes direction even though in high speed (Mansur 2011). Based on those two characteristics, prime physical condition of athlete is requested and evenly distributed to all team member. Main physical conditions that needed in achievement sport athlete are endurance, abdominal muscle strength, speed and flexibility (Sajoto 1988). Cardiovascular endurance is an ability to effectively and efficiently using heart system, respitory and blood circulation continuously (Mukesh 2015) and this condition can be measured using VO2 max. Abdominal muscle strength is an ability to assemble maximum work at abdominal muscle. This condition is important for short movement, fast movement, sport performance and stabilization during explosive movement from extrimicity (Pintar et al 2009). Speed is an ability to do continuous movement in similar form at a short time. This ability is needed by hockey player for convinience during the game (Saini 2016). Flexibility is an ability of a person to move his/her body and some part of the body in one motion room as wide as possible without experience and result any injury at muscle joints. Flexibility is main necessity to run alter training program (Bozic et al 2010).

East Java is one of regions that has some good achievements at Indonesia's indoor hockey in student, undergraduate student, club, or regional championships. Therefore, it needs some attentions related to athlete's physical condition to gain better achievement. This study was to describe the difference of main physical condition between female East Java athlete and National athlete at indoor hockey sport used as milestone to train and arrange some training program from early stage at school until preparation of PON 2020. Given the differences in performance's quality between those players that were not far viewed from the game level, experience, and training duration.

\section{MATERIALS AND METHODS}

This study used analytical observation method. The population of the study consisted of 12 female athletes indoor hockey of East Java from PON 2016 with age range 17-28 years old and 12 female athletes indoor hockey of National from SEA Games 2017 with age range 19-28 years old. Physical conditions measured in this study were endurance, abdominal muscle strength, flexibility, and speed. Measurement being performed was a routine test carried out by KONI of East Java.

\section{Endurance}

To measure cardiovascular efficiency, physical work capacity test and VO2max had been developed to use in laboratory and field situation to help the scientist, physical teacher and trainer (Kumar, 2015). Endurance test being measured was cardiovascular endurance to know athlete's VO2max using multi fitness test (MFT) method (Kumar 2017). Unit that was resulted after conversion was $\mathrm{ml} / \mathrm{kg} /$ minute.

\section{Abdominal Muscle Strength}

This abdominal muscle strength test was measured by sit up test for 60 seconds. The athletes were doing a sit up as much as possible for 60 seconds. This test was done in only one experiment. The more number of sit up gained from the athletes, the better category they were in. The result of this measurement was using times of doing.

\section{Speed}

This speed test was done by the athletes by running as fast as possible in 20 meters. This test was done in two experiments, and the best time was chosen from both of them. The less period of time gained by the athletes, the better speed of physical condition category they were in. This measurement was using stopwatch, and use second as unit.

\section{Flexibility}

This flexibility test was done using 'sit' and 'reach' flexibility tool. The athletes sat with both of their leg forward or touched the measurement beam, then both of their hands were stack straight and push both of their hands on a measurement ruler as far as possible without bending their knee. Number of measurement was placed at the farthest reach of the hand that pushed, so that the farther the push the better flexibility that the athletes had. The final result of this measurement was using centimeter unit.

\section{RESULTS}

This study has resulted data of profile from female athlete of indoor hockey of East Team and National Team. The comparison data of cardiovascular endurance of physical condition (VO2max), speed, abdominal muscle strength, and flexibility can be seen in the following tables: 
Table 1. Profile data from indoor hockey female athletes of East Java Team and National Team

\begin{tabular}{lllll}
\hline Group & & Age & Weight & Height \\
& & $X \pm S D(\mathrm{yr})$ & $\mathrm{X} \pm \mathrm{SD}(\mathrm{Kg})$ & $\mathrm{X} \pm \mathrm{SD}(\mathrm{cm})$ \\
\hline East Java Team & 12 & $21.75 \pm 3.11$ & $51.50 \pm 8.76$ & $156.92 \pm 6.29$ \\
Indonesian National Team & 12 & $23.75 \pm 2.80$ & $51.58 \pm 6.34$ & $155.83 \pm 4.99$ \\
\hline
\end{tabular}

Table 2. Analytical result of endurance comparison (VO2max) between East Java Team and National Team

\begin{tabular}{llllll}
\hline \multicolumn{5}{c}{ ENDURANCE $(\mathrm{ml} / \mathrm{kg} / \mathrm{min})$} \\
\hline Group & mean \pm SD & Min & Max & Range & P value \\
\hline East Java & $34.30 \pm 4.18$ & 34.30 & 47.40 & 13.10 & \multirow{2}{*}{0.14} \\
National & $43.43 \pm 7.59$ & 33.90 & 57.60 & 23.70 & \\
\hline
\end{tabular}

From the previous result of analytical data, the VO2max average of East Java Team was lower compare to National team. The comparison of VO2max between female athlete indoor hockey of East

Table 3. Analytical result of speed comparison between East Java Team and National Team

\begin{tabular}{cccccc}
\hline & \multicolumn{3}{c}{ SPEED $(\mathrm{sec})$} & Range & P value \\
\hline Group & mean \pm SD & Min & Max & 0.97 & 0.51 \\
\hline East Java & $3.59 \pm 0.30$ & 4.06 & 3.09 & 1.26 & 0.62 \\
National & $3.49 \pm 0,39$ & 3.88 & 2.62 & & \\
\hline
\end{tabular}

From the previous result of analytical data, East Java Team and National Team did not show significant difference with ? value $=0.51$. However, time difference of them was not far, where East Java team was 3.59 and National team was 3.49.

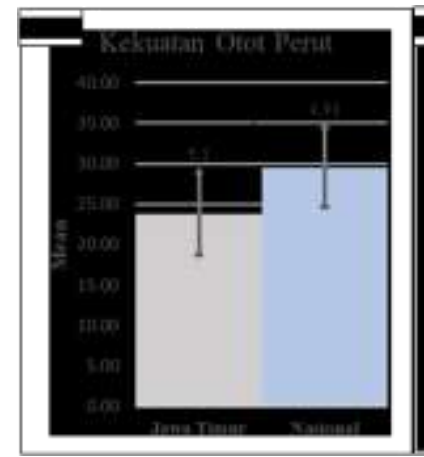

1.a

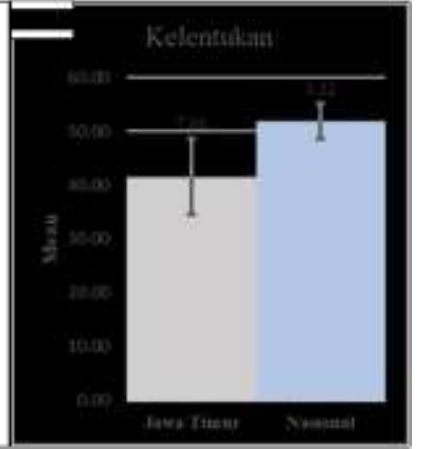

$1 . b$
Figure 1. At 1.a. Showed the differences of abdominal muscle strength. 1.b. Showed the differences of flexibility.

*There were significant differences with $?<0.05$ at $\mathrm{t}$ test.

From the previous result of analytical data, graphic 1. a. showed that the difference of average of abdominal
Java team and National team did not show significant difference with ? value $=0.14$. muscle strength physical condition of East Java Team (23.75) was lower than National Team (29.5). The graphic 1. b. showed that the difference of average of flexibility physical condition of East Java Team was lower than National Team which was only 41.50 and 51.83 in each.

\section{DISCUSSION}

From the comparison of abdominal strength, it showed that there was a significant difference between East Java player $(41,50)$ and National Player $(51,83)$ with ? value $=0,00$. National athlete team showed a better result compared to East Java team. From previous research about abdominal muscle strength on professional female player in India, there were about 48 repetition (Qinney 1984). That difference was not too far for East Java Team to catch if they want to maximize their abdominal muscle strength, so that they could optimum achievement, whereas in this case, there was a supporting research result that discussed how abdominal muscle strength influenced athlete's achivement (Pintar et al 2009).

From the result of flexibility comparison of East Java Team and National Team, there were significant difference between national player with ? value $=0.01$. If 
we compare them with a study on flexibility in Finland which had been participated at international championship, they had an average flexibility of 17.67 $\mathrm{cm}$ (Saini 2016). Meanwhile, the East Java Team was not too far different from them. Flexibility is important aspect of physical condition that the athletes should possess, because it is a basic aspect to perform at training program (Saini 2016). As of East Java Team physical condition could be maintained to be better, so that they could perform in optimum training program.

From the analytical data result of physical condition of cardiovascular endurance by knowing VO2max of both teams' athletes, they were not showing significant difference, but National Team still had better highest number compared to East Java Team, although the lowest number of National Team was lower than East Java Team, so that the result had created a wide range of number. The indoor hockey female athlete of Findland National Team that had previously been measured in previous study gave result of average VO2max of 49.5 $\mathrm{ml} / \mathrm{kg} / \mathrm{min}$ (Peltone 2015). Meanwhile, East Java's athlete had average VO2max of $43.43 \mathrm{ml} / \mathrm{kg} / \mathrm{min}$, and its difference was still from National's athlete or Finland National athlete. Those differences were proven of fact that experienced athlete showed better level of average and consistency. It wasimportant for the coach/trainer to improve VO2max of East Java's athlete to gain better achievement, because endurance was defined as a condition where the body was able to work in long period without getting over exhausted after completing the job (Harsono 1988 in Hendra 2014).

From analytical data result of physical condition of flexibility, the East Java Team and National Team showed significant difference among National athletes with ? value $=0,01$. The significant difference between National athlete and East Java athlete was supported by a wide range of differences between them. Yet, the range was designed not to be too wide. If we compared it with the previous research on flexibility of Finland athletes that had joined in world championship, they had an average of flexibility $17.67 \mathrm{~cm}$ (Saini 2016) and East Java Team was not too far from it. Flexibility is important aspect of physical condition that athletes should possess, because it is a basic aspect to perform training program (Saini 2016). Therefore, by physical condition of East Java Team, they could perform in optimum training program.

The analytical data result of physical condition of speed between East Java Team and National Team was almost the same. The analytic result of speed did not show significant result with ? value $=0,51$. Physical condition of speed analysis did not show significant difference between East Java team and National team. However,
National Team showed a result that they were faster than East Java Team. In comparison, the previous research between hockey athlete and female soccer athlete in India showed a result that hockey athlete has a better speed than soccer athlete in 4.16/4.18 second (Saini 2016). The difference of speed with foreign athlete was not too far, so that it is depends on effort of the coach/trainer to improve the speed physical condition of East Java Team, so that they could be better (Saini 2016).

Physical conditon is an important aspect in sport achievement, because it directly impacts on athlete's performance (Tanner \& Gore 2013). Success in sport is usually a result of planning, hard working, commitment, and athlete's training. All successful athletes are trained individuals who have the best performance at certain physical activity and usually joined long term training program (Bompa \& Carrera 2015).

\section{CONCLUSION}

Indoor hockey female athletes of the National Team had better physical conditions in the components, such as abdominal muscles strength and flexibility, compared to the female athletes of East Java Team. Therefore, it is recommended to improve the physical condition of abdominal muscles strength and flexibility of East Java athlete while keep maintaining other physical condition.

\section{REFERENCES}

Quinney AH, Smith DJ, Wenger HA (1984). A field test for the assessment of abdominal muscular endurance in professional ice hockey players. The Journal of Orthopaedic And Sportsp Hysical Therapy, 6, 30-33.

Andreas E (2009). Field hockey step to sucesss. Australia: Sport Intruction.

Bompa T, Carrera M (2015). Conditioning young athletes. United States: Human Kinetics.

Fathurozi M (2015). Analisis gerak tenik dasar push dan flick terhadap ketepatan sasaran dan efektifitas gerak atlet hoki Sidoarjo. Surabaya: Universitas Negeri Surabaya.

FIH: Hero FIH Ranking Outdoor. (n.d.). Available from: http://www.fih.ch/rankings/outdoor/ orgconflict.htm. Accessed January 7, 2018.

Kumar MS, Mehrotra A (2017). Construction of skill based test item for measuring slap ability in field hockey. International Journal of Physical Education, Sports and Health, 4, 21-23

Kumar, MM (2015). A comparative study of Vo2 max among the basketball, football, volleyball and hockey 
male players. International Journal of Applied Research; 1, 245-247.

Mansur MS (2011). Pemanduan bakat olahraga. Yogyakarta: Universitas Negeri Yogyakarta.

Peltonen O (2015). Physical profile of finnish female ice hockey national team between the years 19952014. Finland: Haaga-Helia university of Apllied Sciences.

Pintar JA, Ken E, Learman, Renee R (2009). Traditional exercises do not have a significant impact on abdominal peak force in healthy young adults. Journal of Strength and Conditioning Research, 23, 20832089

Saini D (2016). Assessment of physical fitness components between hockey and football girls' players of Haryana. International Journal of Physical Education, Sports and Health, 3, 31-33.

Sajoto M (1988). Pembinaan kondisi fisik dalam olahraga. Jakarta: Departemen Pendidikan dan Kebudayaan.

Tanner RK, Gore C (2013). Physiological test for elite atletes. Australia: Australia Institute of Sport. 